\title{
Effect of multivitamins in an effervescent preparation on the respiratory burst of peritoneal macrophages in mice
}

\author{
Judit Jakus*, Tamás Kriska and Rozália Vanyúr \\ Institute of Chemistry, Chemical Research Center, Hungarian Academy of Sciences, 1525 Budapest, PO Box 17, Hungary
}

(Received 6 February 2001 - Revised 18 September 2001 - Accepted 8 January 2002)

\begin{abstract}
The effect of regular intake of low doses of an effervescent multivitamin preparation on the free-radical-producing activity of murine peritoneal macrophages under conditions resembling a possible infection was studied in vitro. Initially, several groups of mice were fed a basal diet and given, for 2 weeks, water without or with supplementation of either $\alpha$-tocopherol, ascorbic acid, riboflavin or a multivitamin preparation. The supplementation period was followed by a 2week wash-out time interval during which control and multivitamin groups received deionized water. Macrophage stimulation tests using chemiluminescent spectroscopy were performed at the end of the supplementation and wash-out periods to determine cell counts and their capacity to produce free radicals. Multivitamin supplementation increased the number, and the reactive oxygen species-producing activity, of macrophages. This effect persisted for 2 weeks after higher doses of supplementation were stopped. Multivitamin supplementation lowered the steady-state free radical concentrations of liver and spleen as measured by electron paramagnetic resonance spectroscopy. It also increased the antioxidant reactivity of the same organs, while there was no effect on the free radical concentration and antioxidant capacity of the kidney and brain. When taken regularly, low doses of multivitamin supplementation may have a beneficial effect on the defence mechanisms of the organism.
\end{abstract}

Vitamins: Reactive oxygen species: Chemiluminescence: Respiratory burst

Nutrition has a great importance in the maintenance of immunity and health of both man and animals (for reviews see: Brown, 1977; Sharmanov, 1982; Burkholder \& Swecker, 1990; Chandra \& Kumari, 1994; Hannigan, 1994; Keusch, 1998; Chandra, 1999). Nutritional deficiencies impair immune responsiveness and, thereby, increase morbidity and mortality. On the other hand, nutritional supplementation of vitamins and minerals often enhances certain aspects of immune function. There is a great number of different vitamin and mineral preparations available in the form of caplets or effervescent tablets recommended for daily consumption in addition to an everyday diet.

A group of vitamins with potent antioxidant activities have recently received a great deal of attention because of their action on immunity and disease aetiology (Bendich, 1996; Meydani et al. 1998; Hughes, 1999). Superoxide anion radical $\left(\mathrm{O}_{2}^{-}\right)$, hydroxyl radical $(\mathrm{HO})$, hydrogen peroxide $\left(\mathrm{H}_{2} \mathrm{O}_{2}\right)$ and singlet oxygen $\left({ }^{1} \mathrm{O}_{2}\right)$ are continuously produced in the course of normal aerobic cellular metabolism and are capable of injurious interactions with cell macromolecules (de Zwart et al. 1999). On the other hand, phagocytic immune cells like neutrophils, monocytes and macrophages, when stimulated undergo respiratory burst to produce high levels of these reactive oxygen species (ROS) to kill invading pathogens (Babior, 1978). Thus, respiratory burst and the consequent high production of ROS play a crucial role in host defence against microorganisms and represents part of the defence mechanisms of the organism.

There are many studies in the literature dealing with the effect of different vitamins on the activity and respiratory burst of phagocytic immune cells. High dietary intakes of vitamin A (retinyl palmitate) increased in vitro phagocytic ability and tumouricidal activity of peritoneal macrophages, as well as mitogenic activity of isolated murine splenocytes (Moriguchi et al. 1985). Additional, but nontoxic, amounts of retinyl palmitate have been shown to lower the susceptibility of rats to salmonella infection in vivo by enhancing phagocytic functions of isolated Kupffer cells, peritoneal and splenic macrophages (Hatchigian et al. 1989). Dietary deprivation of B vitamins, and especially

\footnotetext{
Abbreviations: EPR, electron paramagnetic resonance; ROS, reactive oxygen species.

* Corresponding author: Dr Judit Jakus, fax +361 325 7554, email jakus@chemres.hu
} 
that of riboflavin, significantly lowers the macrophage counts in murine spleen (Matthews et al. 1994). Treatment of monocytic human cell lines with cholecalciferol in vitro increases their phagocytic activity and enhances their oxidative burst capacity (Hauck et al. 1997).

There are several studies showing a cooperative effect among multiple antioxidants (Palozza \& Krynski, 1992; Gilligan et al. 1994; Nyyssonen et al. 1994; Chen \& Tappell, 1995; Knudsen et al. 1996; Thomas et al. 1996; Mosca et al. 1997; Eberlein-König et al. 1998) focusing mainly on protection against oxidative damage of lipids and proteins, but there are not many studies reporting cell-mediated immune responses. Migration and phagocytosis increases when vitamins $\mathrm{C}$ or $\mathrm{E}$ are added to head-kidney leukocytes of gilthead seabream in vitro, while the respiratory burst is synergistically enhanced when both vitamins are used together (Mulero et al. 1998). This is explained by the ability of vitamin $C$ to regenerate membrane-bound oxidized vitamin E (Tappell, 1962; Nikki, 1987; Chan, 1993). Although these vitamins are effective antioxidants in vitro, the results of in vivo and ex vivo studies are conflicting (McCall \& Frei, 1999). An $\alpha$-tocopherol acetate-enriched or -deficient diet failed to significantly activate Kupffer cell phagocytosis and to influence liver injury in rats (Rücker et al. 1997). Vitamin $\mathrm{C}$ when incubated in vitro neutralized the free radicals produced during respiratory burst of murine peritoneal phagocytic cells, but showed no effect on ROS production in cells harvested from mice pretreated with high doses of the vitamin in vivo (Arquette \& Caren, 1992).

Current evidence is insufficient to draw conclusions on the effect of vitamins, and especially of vitamin combinations on the activity of phagocytic immune cells when taken as a supplement to an average diet. Therefore, we studied the effect of a low dose supplementation of a multivitamin preparation on the ROS-producing activity of murine peritoneal macrophages, and compared the results with those obtained in cells isolated from mice supplemented with $\alpha$-tocopherol, ascorbic acid or riboflavin alone. When mentioning low doses of supplementation it has to be considered that animals were kept on a basal, not vitamin-deficient diet, meaning that they have received enough vitamins for the maintenance of normal cell functions on daily basis without any supplementation. We chose a typical effervescent multivitamin preparation readily accessible to consumers, which consists of ten vitamins, each at a dose corresponding to $100 \%$ of the recommended dietary allowance for human adults (National Research Council, 2001).

\section{Materials and methods}

\section{Experimental design}

Five-week-old pathogen-free NMRI (Crl:NMRI BR SPF) male mice weighing 18-20 g were obtained from Charles River Co. (Budapest, Hungary). They were kept under standard conditions and fed a basal preformulated ratmouse diet R/M-Z+H $15 \mathrm{~mm}$ (Ssniff Spezialdiaten $\mathrm{GmbH}$, Soest, Germany). Animals were randomly divided into thirteen groups each containing twenty to twenty-five animals. Food and water were given ad libitum. On average, mice consumed $2 \mathrm{ml}$ water and $2-3 \mathrm{~g}$ chow/d. Four control groups (Control 1, Control 2, Control 3 and Control 4) received basal diet and deionized water only, while two placebo groups (Placebo 1 and Placebo 2) received the basal diet for a 2-week period and an effervescent placebo in their drinking water, which contained the carrier components of the multivitamin supplement at two different concentrations without the vitamins. The other seven groups received basal diet and drinking water supplemented with an effervescent preparation containing either vitamin $\mathrm{E}$ in the form of $\alpha$-tocopherol acetate ( $\alpha$-Tocopherol group), vitamin $\mathrm{C}$ or ascorbic acid (Ascorbic acid group), Vitamin $\mathrm{B}_{2}$ or riboflavin (Riboflavin group), or a multivitamin complex (Plusssz Multivitamin formulated by Pharmavit Rt., a Bristol-Myers Squibb Company, Veresegyház Hungary) at two different concentrations (Multivitamin 1 and Multivita$\min 2$ groups at $2 \mathrm{X}$ dose, Multivitamin 3 and Multivitamin 4 groups at $5 \mathrm{X}$ dose ( $2 \mathrm{X}$ meaning a dose (calculated based on a $20 \mathrm{~g}$ mouse body weight) that is twofold, and $5 \mathrm{X}$ meaning a dose that is fivefold, the recommended dietary allowance for human adults)). Based on the manufacturer's formulation of the rat-mouse chow R/M-Z+H (Ssniff Spezialdiaten $\mathrm{GmbH}$ ), the $2 \mathrm{X}$ dose did not exceed $10 \%$ of an average daily vitamin intake of the mice). After 2 weeks, animals from Control 1 and 3, Placebo 1 and 2, Vitamin E, Vitamin $C$, Vitamin $B_{2}$, Multivitamin 1 and 3 groups were killed: elicited peritoneal macrophage cells were isolated from ten animals and organs from the remaining ten to fifteen animals extracted for free radical measurements. Control 2 and 4, Multivitamin 2 and 4 groups were given the basal diet and deionized water without supplementation for another 2 weeks (wash-out period), and killed 4 weeks after the beginning of the experiment. The vitamin content and doses of supplementation are given in Table 1. The protocol and animal care was approved by the local Committee for the Care and Use of Laboratory Animals in accordance with the European Community guidelines.

\section{Cell culture}

Mice were injected intraperitoneally with $1 \mathrm{ml}$ sterile sodium caseinate (100 g/l; Sigma, St Louis, MO, USA) prepared in $\mathrm{NaCl}(9 \mathrm{~g} / \mathrm{l})$. Elicited macrophages were harvested by peritoneal lavage $48 \mathrm{~h}$ after injection of caseinate: $5 \mathrm{ml}$ RPMI 1640 medium (Sigma) containing fetal calf serum $\left(100 \mathrm{ml} / \mathrm{l}\right.$; Gibco BRL ${ }^{\mathrm{TM}}$, Life Technologies Ltd., Paisley, UK) and heparin $(5 \mathrm{u} / \mathrm{ml})$ was injected into the peritoneal cavity, which was then massaged, and the fluid withdrawn. An additional $5 \mathrm{ml}$ portion of the medium was injected into the cavity and the procedure repeated. The peritoneal exudate cells (primarily macrophages) were counted, viability tests performed using trypan blue staining, and viable cell concentration was adjusted in the same medium to $2 \times 10^{6}$ cells in each glass cuvette of the luminometer. To obtain a homogeneous macrophage monolayer, incubations were performed for $2 \mathrm{~h}$ at $37^{\circ} \mathrm{C}$ in the glass cuvettes, after which the non-adhered cells (macrophages and lymphocytes) were washed off with Hank's balanced salt solution (Sigma; $\mathrm{pH} 7 \cdot 2$ ). 
Table 1. Content and doses of effervescent vitamin supplementation in mice

\begin{tabular}{|c|c|c|c|c|}
\hline \multirow[b]{3}{*}{ Vitamins* } & \multicolumn{4}{|c|}{ Daily dose } \\
\hline & \multicolumn{2}{|c|}{$2 X \dagger$} & \multicolumn{2}{|c|}{$5 X \dagger$} \\
\hline & $\mathrm{mg} / \mathrm{kg}$ body weight per $\mathrm{d}$ & $\mu \mathrm{g} / \mathrm{ml}$ drinking water & $\mathrm{mg} / \mathrm{kg}$ body weight per $\mathrm{d}$ & $\mu \mathrm{g} / \mathrm{ml}$ drinking water \\
\hline$\alpha$-Tocopherol & 0.3 & 3.0 & & \\
\hline Ascorbic acid & $2 \cdot 0$ & $20 \cdot 0$ & & \\
\hline Riboflavin & 0.05 & 0.5 & & \\
\hline \multicolumn{5}{|l|}{ Multivitamin: } \\
\hline$\alpha$-Tocopherol & 0.3 & 3.0 & 0.75 & 7.5 \\
\hline Ascorbic acid & $2 \cdot 0$ & $20 \cdot 0$ & $5 \cdot 0$ & $50 \cdot 0$ \\
\hline Thiamin & 0.04 & 0.4 & 0.1 & 1.0 \\
\hline Riboflavin & 0.05 & 0.5 & 0.125 & 1.25 \\
\hline Pyridoxine & 0.06 & 0.6 & 0.15 & 1.5 \\
\hline Cyanocobalamin & $0.03 \times 10^{-3}$ & $3.0 \times 10^{-4}$ & $0.075 \times 10^{-3}$ & $7.5 \times 10^{-4}$ \\
\hline Folic acid & 0.006 & 0.06 & 0.015 & 0.15 \\
\hline Biotin & 0.004 & 0.04 & 0.01 & 0.1 \\
\hline Nicotinamide & 0.5 & $5 \cdot 0$ & 1.25 & $12 \cdot 5$ \\
\hline Pantothenic acid & 0.17 & 1.7 & 0.425 & 4.25 \\
\hline
\end{tabular}

*Vitamins were formulated by Pharmavit Rt., a Bristol-Myers Squibb Co., Hungary.

$\dagger 2 \mathrm{X}, 5 \mathrm{X}$, doses corresponding to two- and fivefold the recommended dietary allowance for adult humans (National Research Council, 2001) based on body weight.

\section{Luminol-dependent chemiluminescence measurements}

Details of chemiluminescence measurements have been described by us earlier (Gál et al. 1997; Kriska et al. 1999). In summary, measurements were performed by a VG-05-type computer-controlled chemiluminometer (Central Research Institute for Chemistry, Hungarian Academy of Sciences, Budapest, Hungary) with a 9658 EMI (S-20) type photomultiplier. Macrophages were stimulated with $0.5 \mathrm{mg}$ zymosan $/ \mathrm{ml}$ obtained from Sigma (Castranova et al. 1987). The reaction mixture $(2 \mathrm{ml})$ contained $100 \mu \mathrm{M}$-luminol, bovine serum albumin ( $\mathrm{g} / \mathrm{l}$; Sigma), and glucose (2 g/l; Sigma). Luminol, 3-aminophthalhydrazide, was purchased from Sigma and prepared as a stock solution in dimethylsulfoxide at a concentration of $100 \mathrm{~mm}$.

\section{Measurement of total antioxidant reactivity of tissue homogenates}

The capacity of biological samples to scavenge free radicals was determined based on the method described by Lissi et al. (1995), which monitors the intensity of luminol-induced chemiluminescence by radicals derived from the thermolysis of $2,2^{\prime}$-azo-bis(2-amidinopropane). The luminescence intensity is quenched by the addition of biological fluids or samples like tissue homogenates. Briefly, approximately $100 \mathrm{mg}$ liver or spleen tissue were homogenized in PBS solution on an ice bath using an Elvehjem (Wheaton Science Products, Millville, NJ, USA) potter to a final homogenate concentration of $100 \mathrm{~g} / \mathrm{l}$. The homogenates were centrifuged at $500 \mathrm{~g}$ for $10 \mathrm{~min}$ at $4{ }^{\circ} \mathrm{C}$ and supernatant fractions were used for measurements of antioxidant reactivity. Homogenates $(25 \mu \mathrm{l})$ were added to $2.7 \mathrm{ml}$ $100 \mathrm{~mm}$-glycine buffer, $\mathrm{pH} 8.6$ containing $10 \mu \mathrm{M}$-luminol at $40^{\circ} \mathrm{C}$ in the cuvette of the chemiluminometer. $100 \mathrm{~mm}-$ 2,2'-azo-bis(2-amidinopropane) (Fluka, Buchs, Switzerland) $(-0.3 \mathrm{ml}$, final concentration $10 \mathrm{~mm})$, were added to the reaction mixture and measurements started right away. Trolox, (( \pm )-6-hydroxy-2,5,7,8-tetra-methylchromane-2-carboxylic acid), a soluble vitamin $\mathrm{E}$ derivative purchased from Fluka, was used as standard to quantify the reductive capacity of tissue samples.

\section{Electron paramagnetic resonance measurements of frozen tissue samples}

Electron paramagnetic resonance (EPR) spectroscopy is a direct method for detection of free radicals and was used to measure the in vivo generated free-radical concentration of tissue samples. Tissue sampling was accomplished within 5 min of killing the animals (when the organs are still alive) by freezing an approximately $100 \mathrm{mg}$ rodshaped piece of brain, kidney, spleen and liver in liquid $\mathrm{N}_{2}$. The spectra were obtained using an X-band computer-controlled spectrometer with a $100 \mathrm{kHz}$ modulation frequency constructed by Magnettech $\mathrm{GmbH}$ (Berlin, Germany). Measurements were performed in a quartz finger-dewar filled up with liquid $\mathrm{N}_{2}$ in a similar way to that described earlier (Shulyakovskaya et al. 1993). The concentrations of free radicals were determined using a $\mathrm{MnO}-\mathrm{Mn}$ internal standard and an EPR simulation program developed by Dr Antal Rockenbauer (Rockenbauer \& Korecz, 1996) at the Technical University of Budapest, Hungary.

\section{Statistical analyses}

Unpaired Student's $t$ test was used to determine the significance of the differences between mean values of the groups using Statistica ${ }^{\mathrm{TM}}$ program package (Statsoft, Tulsa, OK, USA). Differences associated with $P$ values $<0.05$ or $<0.01$ were regarded as statistically significant. 


\section{Results}

Compared with control groups, the placebo induced no significant changes in any of the measured variables.

The number of elicited peritoneal macrophages increased in caseinate-injected animals that were pretreated with $\alpha$-tocopherol, riboflavin or the multivitamin complex, but had no effect in animals pretreated with ascorbic acid in a dose that was twofold the recommended dietary allowance for human adults (National Research Council, 2001) (Table 2). The cell counts in mice given the multivitamin preparation remained high for 2 weeks after supplementation was terminated and animals were given basic diet and deionized water again.

We have shown previously (Gál et al. 1997) that luminol-dependent chemiluminescence during respiratory burst of zymosan-stimulated macrophage cell cultures gives an asymmetrical bell-shaped curve, while resting cells give no detectable signal. Under controlled conditions, this is a useful model for quantitative evaluation of the amount of ROS produced by cells in vitro (Németh et al. 1999). Figure 1 shows a typical luminoldependent chemiluminescence response of zymosan-stimulated murine peritoneal macrophages elicited from control and multivitamin-supplemented mice for 2 weeks. Addition of $1 \mathrm{~mm}-N^{\mathrm{G}}$-methyl-L-arginine, an NO synthase inhibitor to the reaction mixture had no effect on the intensity of the signal (results not shown), suggesting no significant contribution of $\mathrm{NO}$ radicals to luminol-dependent chemiluminescence.

The ability of stimulated macrophages to produce ROS was elevated only in cells elicited from animals supplemented with riboflavin and the multivitamin preparation compared with control and placebo groups (Table 2). Values obtained with cells isolated from multivitaminsupplemented animals were significantly higher than those obtained in cells isolated from animals pretreated with $\alpha$-tocopherol, ascorbic acid or riboflavin alone, showing an additive effect. This difference in ROS-producing capacity of cells isolated from the multivitamin group disappeared after the 2-week wash-out period. Results were similar when the experiment was repeated with a higher dose of the multivitamin mixture, fivefold the recommended dose for adult humans (National Research Council, 2001) (Table 3). In this case, however, macrophages retained their high ROS-producing ability even after the 2-week wash-out period, suggesting that the effect of some of the vitamins on the activity of immune cells persists longer when taken at higher doses.

In order to see how multivitamin supplementation affects the overall free-radical concentration of some of the organs, we have measured the steady-state free-radical concentration of the spleen, liver, kidney and brain tissues using EPR spectroscopy. Samples submerged in liquid $\mathrm{N}_{2}$ give rise to a broad and intense singlet, which is the envelope of EPR signals derived from many organic radicals (Reynolds \& Moslen, 1980). Figure 2 represents a typical EPR spectrum of the kidney, where points indicate the measured values and the line shows the simulated spectrum.

Results in Table 4 have been derived from the measured EPR signals and show that the overall free radical concentration of the liver and spleen was affected by the 2-week supplementation with $\alpha$-tocopherol, riboflavin and the multivitamin preparation, whereas the free-radical content of the kidney and brain remained unchanged. The differences

Table 2. Number of elicited peritoneal macrophages and their reactive oxygen species (ROS)-producing capacity in mice drinking different solutions of vitamins at a $2 \mathrm{X}$ dose $\S$ for 2 weeks and after a wash-out period of another 2 weeks\|

(Mean values and standard deviations for nine or ten mice per group)

\begin{tabular}{|c|c|c|c|c|c|c|}
\hline \multirow[b]{3}{*}{ Vitamins } & \multirow{2}{*}{\multicolumn{2}{|c|}{$\begin{array}{c}\text { No. of } \\
\text { macrophages } \\
\left(n \times 10^{6} \text { cells }\right)\end{array}$}} & \multicolumn{4}{|c|}{ ROS-producing activity $\left(2 \times 10^{6}\right.$ cells $)$} \\
\hline & & & \multicolumn{2}{|c|}{$\%$ Control } & \multicolumn{2}{|c|}{$\%$ Placebo } \\
\hline & Mean & SD & Mean & SD & Mean & SD \\
\hline \multicolumn{7}{|c|}{ After 2-week supplementation at a $2 \mathrm{X}$ dose§ } \\
\hline Control 1 & 6.49 & 1.84 & 100 & & & \\
\hline Placebo 1 & $5 \cdot 76$ & 0.98 & $112 \cdot 1$ & $16 \cdot 6$ & 100 & \\
\hline$\alpha$-Tocopherol & $9 \cdot 79^{*}+\dagger$ & 1.02 & 132.9 & 49.5 & 118.5 & 43.4 \\
\hline Ascorbic acid & 7.08 & 0.75 & $163 \cdot 4$ & $52 \cdot 4$ & $145 \cdot 9$ & $46 \cdot 3$ \\
\hline Riboflavin & $12 \cdot 5^{\star} \dagger \dagger$ & 2.96 & $177 \cdot 9^{\star}$ & $54 \cdot 1$ & $158 \cdot 8 \dagger$ & $38 \cdot 3$ \\
\hline Multivitamin 1 & $11.06^{\star}+\dagger$ & $2 \cdot 26$ & $253 \cdot 2^{\star *} \ddagger$ & $72 \cdot 4$ & 226.1††‡ & 64.2 \\
\hline \multicolumn{7}{|c|}{ After 2-week wash-out period } \\
\hline Control 2 & $5 \cdot 95$ & 1.23 & 100 & & & \\
\hline Multivitamin 2 & $10 \cdot 34^{*}$ & 1.67 & 134.5 & $28 \cdot 2$ & & \\
\hline
\end{tabular}

Mean values were significantly different from those of the control groups: ${ }^{\star} P<0.05,{ }^{* \star} P<0.01$. Mean values were significantly different from those of the placebo group: $+P<0.05,+\dagger P<0.01$. Mean values were significantly different from those of individual vitamin treatments: $\ddagger P<0.05$.

$\S 2 X$, dose corresponding to twofold the recommended dietary allowance for adult humans (National Research Council, 2001) based on body weight.

|| For details of diets, supplements and procedures, see Table 1 and p. 502. Peritoneal exudate cells (primarily macrophages) were counted and, viability tests performed using trypan blue staining. ROS-producing ability was measured based on luminol-dependent chemiluminescence during respiratory burst of zymosan-stimulated macrophage cell cultures in vitro.

I Vitamins were formulated by Pharmavit Rt., a Bristol-Myers Squibb Co., Hungary. 


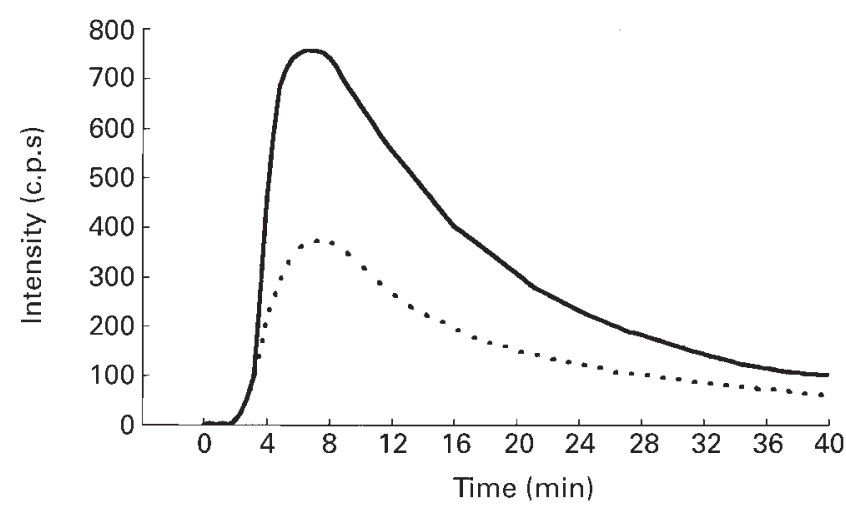

Fig. 1. Time course of luminol-dependent chemiluminescence of stimulated murine peritoneal macrophages elicited from control mice and mice supplemented with multivitamin preparation for 2 weeks. - , Multivitamin; ----, control. For details of diets, supplement and procedures, see Table 1 and p. 502. To obtain a monolayer, $2 \times 10^{6}$ cells were incubated for $2 \mathrm{~h}$ at $37^{\circ} \mathrm{C}$ in a glass cuvette of the luminometer. After several washes, macrophages were stimulated with $0.5 \mathrm{mg}$ zymosan $/ \mathrm{ml}$ in a medium containing $100 \mu \mathrm{M}$-luminol (time 0). The emitted light was measured using a chemiluminescence spectrometer.

disappeared 2 weeks after the termination of supplementation. We looked at the total antioxidant reactivity of liver and spleen (Table 5) and found that their reductive capacity has been significantly increased in cases of $\alpha$ tocopherol-, multivitamin-, and/or ascorbic acid-, riboflavin-pretreatment.

\section{Discussion}

Macrophages stimulated in vitro with zymosan (phagocytizable yeast-cell-wall particles) give a respiratory burst response similar to that of resident cells during the phagocytosis, which is a key process in combating infections in man and animals. The effect on the respiratory burst capacity of macrophages upon stimulation was additive in animals pretreated with multivitamins compared with those given only additional $\alpha$-tocopherol, ascorbic acid or riboflavin (Tables $2(\mathrm{~A})$ and $3(\mathrm{~A})$ ). These results indicate that even low doses of multivitamins taken as a supplement to the basal diet are able to modulate the functions of macrophages. There was no concentrationdependent difference in the magnitude but in the duration of the ROS-producing response, suggesting that lower doses of multivitamins are enough to obtain the maximum effect.

Among non-enzymatic antioxidant $\alpha$-tocopherol, ascorbic acid and riboflavin are of major importance (Abrams et al. 1993; Böhles, 1997). $\alpha$-Tocopherol is the most relevant radical scavenger in lipid phases, while ascorbic acid is a potent antioxidant in aqueous fluids and cell compartments. Riboflavin acts mainly as cofactor of glutathione reductase keeping glutathione in reduced state. It can therefore be considered as an indirect watersoluble antioxidant vitamin. Our findings show that not only high (Moriguchi et al. 1990; Gore \& Qureshi, 1997), but also low doses of $\alpha$-tocopherol supplementation are able to increase the number of elicited macrophages in vivo. This could be due to a vitamin-induced enhancement of macrophage proliferation or to the migration of these cells in higher proportions to the peritoneum of $\alpha$-tocopherol-supplemented animals. Carotenoids and $\alpha$-tocopherol have been reported to increase the proliferative capacity of phagocytic cells (Moriguchi et al. 1990; Chew, 1995), while ascorbic acid and $\alpha$-tocopherol were able to increase their migration (Mulero et al. 1998; Del Rio et al. 1998). In our present case, the cause of higher cell numbers has yet to be established. Interestingly, supplementation with low doses of riboflavin increased not only the number, but also the ROS-producing activity of

Table 3. Number of elicited peritoneal macrophages and their reactive oxygen species (ROS)-producing capacity in mice drinking different solutions of vitamins at a $5 \mathrm{X}$ dose $\neq$ for 2 weeks and after a wash-out period of another 2 weeks§ (Mean values and standard deviations for ten mice per group)

\begin{tabular}{|c|c|c|c|c|c|c|}
\hline \multirow[b]{3}{*}{ Vitamins $\|$} & \multirow{2}{*}{\multicolumn{2}{|c|}{$\begin{array}{c}\text { No. of } \\
\text { macrophages } \\
\left(n \times 10^{6} \text { cells }\right)\end{array}$}} & \multicolumn{4}{|c|}{ ROS-producing activity $\left(2 \times 10^{6}\right.$ cells $)$} \\
\hline & & & \multicolumn{2}{|c|}{$\%$ Control } & \multicolumn{2}{|c|}{$\%$ Placebo } \\
\hline & Mean & SD & Mean & SD & Mean & SD \\
\hline \multicolumn{7}{|c|}{ After 2-week supplementation at a 5X dose $¥$} \\
\hline Control 3 & $6 \cdot 23$ & $1 \cdot 70$ & 100 & & & \\
\hline Placebo 2 & $5 \cdot 22$ & $1 \cdot 18$ & $119 \cdot 3$ & $15 \cdot 1$ & 100 & \\
\hline Multivitamin 3 & $12 \cdot 56 \dagger \dagger$ & 1.89 & $229 \cdot 5^{\star *}$ & $36 \cdot 3$ & 192.4†† & $24 \cdot 1$ \\
\hline \multicolumn{7}{|c|}{ After 2-week wash-out period } \\
\hline Control 4 & 5.92 & $1 \cdot 16$ & 100 & & & \\
\hline Multivitamin 4 & $9 \cdot 98^{* *}$ & 1.02 & $172 \cdot 8^{\star *}$ & $15 \cdot 3$ & & \\
\hline
\end{tabular}

Mean values were significantly different from those of the control groups: ${ }^{\star \star} P<0 \cdot 01$.

Mean values were significantly different from those of the placebo group: $\uparrow \dagger P<0 \cdot 01$.

$\ddagger 5 X$, dose corresponding to fivefold the recommended dietary allowance for adult humans (National Research Council, 2001) based on body weight.

$\S$ For details of diets, supplements and procedures, see Table 1 and p. 502. Peritoneal exudate cells (primarily macrophages) were counted and viability tests performed using trypan blue staining. Ros-producing ability was measured based on luminol-dependent chemiluminescence during respiratory burst of zymosan-stimulated macrophage cell cultures in vitro.

|| Vitamins were formulated by Pharmavit Rt., a Bristol-Myers Squibb Co., Hungary. 


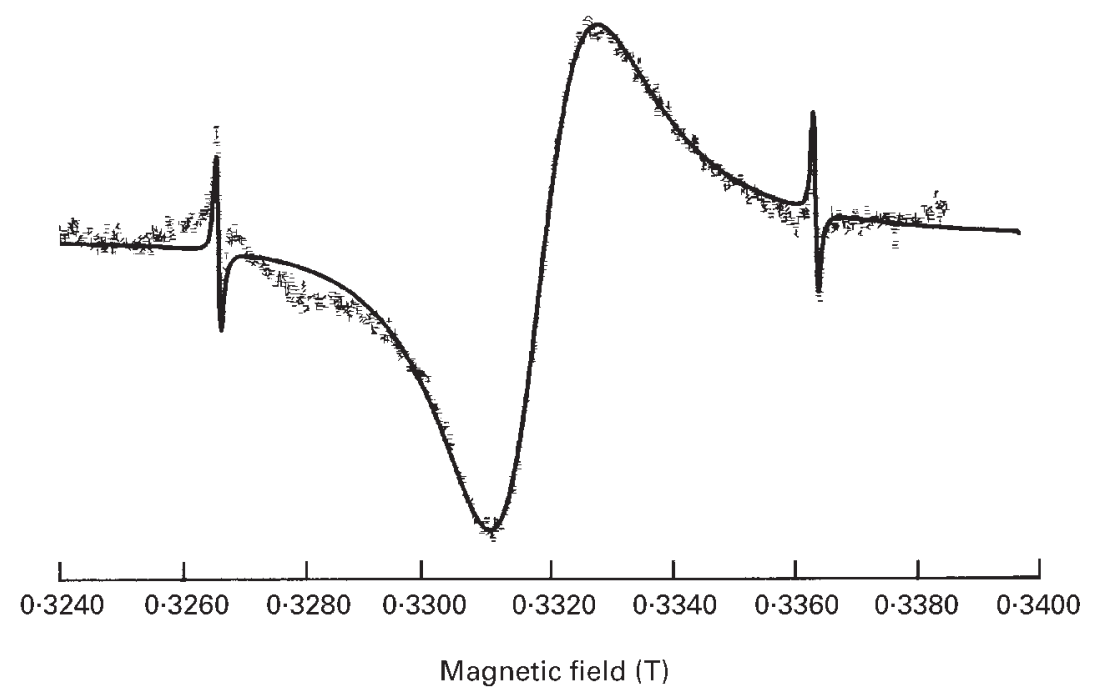

Fig. 2. Typical electron paramagnetic resonance spectrum of the kidney between two manganese peaks. Measurements were performed using an X-band electron paramagnetic resonance spectrometer in a quartz finger-dewar filled up with liquid nitrogen. The concentrations of free radicals were determined using a $\mathrm{MnO}-\mathrm{Mn}$ internal standard. For details of procedures see p. 502. Points indicate the measured values and the line shows the simulated spectrum.

peritoneal macrophages, a phenomenon never reported before. $\alpha$-Tocopherol has been shown to suppress Kupffer cell activation at points beyond the initiation of activation and free-radical release in vitro (Fox et al. 1997). This may explain why $\alpha$-tocopherol was not effective in increasing ROS-producing activity of peritoneal macrophages.

It should be mentioned that in our present study we used cells that were elicited into the peritoneal cavity by prior injection of caseinate and stimulated to produce ROS by addition of zymosan in vitro. Under normal circumstances, macrophages become activated after an infection with parasites. Elicited or activated peritoneal macrophages respond to stimulation with particles or other agents much more vigorously than do resident cells (for review see Badwey \& Karnovsky, 1980). Therefore, one must take account of the state of their 'activation'. Our present results refer to an elicited macrophage population and show that multivitamin supplementation of the diet can modify their ROS-producing ability after being stimulated in vitro, as it could possibly happen in the case of an in vivo infection.

Free-radical mechanisms of liver injury have been proposed for a number of xenobiotic compounds. Only $\alpha$ tocopherol and multivitamin supplementations were able

Table 4. Concentration of free radicals in the organs of mice drinking different solutions of vitamins at a $2 X$ dose $\nmid$ for 2 weeks and after a wash-out period of another 2 weeks $\ddagger$

(Mean values and standard deviations for ten to fifteen mice per group)

\begin{tabular}{|c|c|c|c|c|c|c|c|c|}
\hline \multirow[b]{3}{*}{ Vitamins§ } & \multicolumn{8}{|c|}{ Concentration of free radicals $(\mathrm{AU})$} \\
\hline & \multicolumn{2}{|c|}{ Liver } & \multicolumn{2}{|c|}{ Kidney } & \multicolumn{2}{|c|}{ Spleen } & \multicolumn{2}{|c|}{ Brain } \\
\hline & Mean & SD & Mean & SD & Mean & SD & Mean & SD \\
\hline \multicolumn{9}{|c|}{ After 2-week supplementation at 2X dose $†$} \\
\hline Control 1 & 1028 & 194 & 1154 & 177 & 412 & 105 & 93 & 13 \\
\hline Placebo 1 & 986 & 158 & 1305 & 158 & 410 & 79 & 92 & 17 \\
\hline$\alpha$-Tocopherol & $827^{\star *}$ & 125 & 1042 & 153 & $318^{\star *}$ & 53 & 99 & 15 \\
\hline Ascorbic acid & 949 & 121 & 1063 & 201 & 389 & 97 & 114 & 20 \\
\hline Riboflavin & 1030 & 184 & 1084 & 125 & $310^{\star \star}$ & 52 & 111 & 23 \\
\hline Multivitamin 1 & $889^{*}$ & 174 & 1152 & 174 & $337^{\star}$ & 54 & 97 & 9 \\
\hline \multicolumn{9}{|c|}{ After 2-week wash-out period } \\
\hline Control 2 & 1124 & 170 & 1020 & 119 & 445 & 146 & 91 & 13 \\
\hline Multivitamin 2 & 1177 & 162 & 1268 & 215 & 381 & 131 & 100 & 14 \\
\hline
\end{tabular}

Mean values were significantly different from those of the control groups: ${ }^{*} P<0.05{ }^{* \star} P<0.010$.

$+2 X$, dose corresponding to twofold the recommended dietary allowance for adult humans (National Research Council, 2001) based on body weight.

†For details of diets, supplements and procedures, see Table 1 and p. 502. The concentration of free radicals was determined using electron paramagnetic spectroscopy of tissue samples frozen in liquid nitrogen.

$\S$ Vitamins were formulated by Pharmavit Rt., a Bristol-Myers Squibb Co., Hungary. 
Table 5. Total antioxidant reactivity of liver and spleen homogenates prepared from mice drinking different solutions of vitamins at a $2 \mathrm{X}$ dose† for 2 weeks and after a wash-out period of another 2 weeks $\ddagger$

(Mean values and standard deviations for ten mice per group)

\begin{tabular}{|c|c|c|c|c|}
\hline \multirow[b]{3}{*}{ Vitamins§ } & \multicolumn{4}{|c|}{$\begin{array}{l}\text { Total antioxidant reactivity } \\
(\mu \mathrm{mol} \text { free radicals/g tissue) }\end{array}$} \\
\hline & \multicolumn{2}{|c|}{ Liver } & \multicolumn{2}{|c|}{ Spleen } \\
\hline & Mean & SD & Mean & SD \\
\hline \multicolumn{5}{|c|}{ After 2-week supplementation at $2 \mathrm{X}$ dose } \\
\hline Control 1 & 936 & 207 & 248 & 181 \\
\hline Placebo 1 & 864 & 192 & 332 & 108 \\
\hline$\alpha$-Tocopherol & $1524^{\star *}$ & 380 & $1161^{* *}$ & 276 \\
\hline Ascorbic acid & 1205 & 362 & $994^{\star *}$ & 202 \\
\hline Riboflavin & 987 & 196 & $757^{\star *}$ & 96 \\
\hline Multivitamin 1 & $1318^{\star \star}$ & 263 & $1634^{* *}$ & 453 \\
\hline \multicolumn{5}{|c|}{ After 2-week wash-out period } \\
\hline Control 2 & 835 & 205 & 246 & 159 \\
\hline Multivitamin 2 & 962 & 183 & 462 & 193 \\
\hline
\end{tabular}

Mean values were significantly different from those of the control groups: ${ }^{\star *} P<0.01$.

$+2 \mathrm{X}$, dose corresponding to twofold the recommended dietary allowance for adult humans (National Research Council, 2001) based on body weight.

$\ddagger$ For details of diets, supplements and procedures, see Table 1 and p. 502 .

$\S$ Vitamins were formulated by Pharmavit Rt., a Bristol-Myers Squibb Co., Hungary.

to lower the overall concentration of free radicals in the liver (Table 4). This seems to be related to the fact that liver is one of the best antioxidant-supplied organs (Fehér et al. 1992) and it has the largest storage capacity for $\alpha$-tocopherol (Bjørneboe et al. 1991; Surai et al. 1996). In our present experiments we have not measured the concentration of vitamins in any of the organs, but the antioxidant reactivity of liver homogenates prepared from animals supplemented with $\alpha$-tocopherol (Table 5) suggests that it was able to lower the steady-state level of free radicals by virtue of its ability to enhance the reductive capacity of the liver. Results obtained in spleen homogenates showed a similar correlation between the lower free-radical concentrations and higher antioxidant capacity of the organ.

In conclusion, low-dose supplementation of a basal mouse diet with a multivitamin mixture for 2 weeks was enough to enhance the ROS-producing activity of elicited peritoneal macrophages when stimulated with a pathogen-like substance. This increase may imply a higher phagocyte microbial killing power of these important immune cells. Del Rio et al. (1998) showed that several antioxidants when added to cells at low concentrations in vitro not only induced the production of superoxide anion, but also stimulated the phagocytic process in peritoneal macrophages. Supplementation of the diet with the multivitamin preparation did not increase the overall free-radical concentration of any organs studied, showing no potential danger of cell injury. In contrast, intake of some vitamins improved the endogenous defence system of the liver and spleen in the protection of cell components against attack by reactive species. The results presented here are not sufficient to decide which component or components of the multivitamin preparation are responsible for the observed effect. Moreover, ascorbic acid is synthesized by mice, hence the effects of supplementation with this vitamin are difficult to extrapolate to man, who lacks endogenous ascorbic acid.

Nonetheless, it seems that supplementation of the diet with low doses of the multivitamin preparation modulates the immune functions of macrophages by enhancing their ROS-producing activity, and contributes to the overall defence mechanism of some organs against damaging free radicals. More detailed evaluation of different vitamin combinations would provide insight into the in vivo contribution of each component to the beneficial effect of multivitamins on immune cells.

\section{Acknowledgements}

We are grateful to Dr János Gyimesi from Pharmavit Rt., a Bristol-Myers Squibb Company (Hungary), for providing us with the effervescent vitamin samples used in the study.

\section{References}

Abrams B, Duncan D \& Hertz-Picciotto I (1993) A prospective study of dietary intake and acquired immune deficiency syndrome in HIV-seropositive homosexual men. Journal of Acquired Immune Deficiency Syndromes 6, 949-958.

Arquette D \& Caren LD (1992) Effect of sodium ascorbate on the chemiluminescent response of murine peritoneal exudate cells. Life Sciences 50, 753-759.

Babior MB (1978) Oxygen-dependent microbial killing in phagocytes. New England Journal of Medicine 298, 659-668.

Badwey JA \& Karnovsky ML (1980) Active oxygen species and the functions of phagocytic leukocytes. Annual Review of Biochemistry 49, 695-726.

Bendich A (1996) Antioxidant vitamins and human immune responses. Vitamins and Hormones 52, 35-62.

Bjørneboe A, Nenseter MS, Hagen BF, Bjørneboe GE, Prydz K \& Drevon CA (1991) Effect of dietary deficiency and supplementation with all-rac- $\alpha$-tocopherol on hepatic content in rats. Journal of Nutrition 121, 1208-1213.

Böhles H (1997) Antioxidative vitamins in prematurely and maturely born infants. International Journal for Vitamin and Nutrition Research 67, 321-328.

Brown RE (1977) Interaction of nutrition and infection in clinical practice. Pediatric Clinics of North America 24, 241-252.

Burkholder WJ \& Swecker WS Jr (1990) Nutritional influences on immunity. Seminars in Veterinary Medicine and Surgery (Small Animals) 5, 154-166.

Castranova V, Van Scott MR \& Van Dyke K (1987) Isolation and identification of phagocytic cells. In Cellular Chemiluminescence, vol. I, pp. 25-38 [K Van Dyke and V Castranova, editors]. Boca Raton, FL: CRC Press.

Chan AC (1993) Partners in defense, vitamin E and vitamin C. Canadian Journal of Physiology and Pharmacology 71, $725-731$.

Chandra RK (1999) Nutrition and immunology: from the clinic to cellular biology and back again. Proceedings of the Nutrition Society 58, 681-683.

Chandra RK \& Kumari S (1994) Nutrition and immunity: an overview. Journal of Nutrition 124, Suppl. 8, 1433S-1435S.

Chen H \& Tappell AL (1995) Protection of vitamin E, selenium, trolox C, ascorbic acid palmitate, acetylcysteine, coenzyme $\mathrm{Q}_{10}$, beta-carotene, canthaxanthin, and (+)-catechin against 
oxidative damage to rat blood and tissue in vivo. Free Radical Biology and Medicine 18, 949-953.

Chew BC (1995) Antioxidant vitamins affect food animal immunity and health. Journal of Nutrition 125, 1804S-1808S.

Del Rio M, Ruedas G, Medina S, Victor VM \& De la Fuente M (1998) Improvement by several antioxidants of macrophage function in vitro. Life Sciences 63, 871-881.

de Zwart LL, Meerman JHN, Commandeur JNM \& Vermeulen NPE (1999) Biomarkers of free radical damage. Applications in experimental animals and in humans. Free Radical Biology and Medicine 26, 202-226.

Eberlein-König B, Placzek M \& Przybilla B (1998) Protective effect against sunburn of combined systemic ascorbic acid (vitamin $\mathrm{C}$ ) and $\mathrm{D}-\alpha$-tocopherol (vitamin $\mathrm{E}$ ). Journal of the American Academy of Dermatology 38, 45-48.

Fehér J, Vereckei A \& Lengyel G (1992) Role of free radical reactions in liver diseases. Acta Physiologica Hungarica 80, $351-361$.

Fox ES, Brower JS, Bellezzo JM \& Leingang KA (1997) $\mathrm{N}$ acetylcysteine and $\alpha$-tocopherol reverse the inflammatory response in activated rat Kupffer cells. Journal of Immunology 158, 5418-5423.

Gál D, Kriska T \& Maltseva E (1997) In vivo experimental studies on the role of free radicals in photodynamic therapy. III. Photodynamic effect on free radicals generated in cell cultures. Biochemical and Biophysical Research Communications 233, 173-176.

Gilligan DM, Sack MN, Gietta V, Casino PR, Quyyumi AA, Rader DJ, Panza JA \& Cannon RO (1994) Effect of antioxidant vitamins on low density lipoprotein oxidation and impaired endothelium-dependent vasodilation in patients with hypercholesterolemia. Journal of the American College of Cardiology 24, 1611-1617.

Gore AB \& Qureshi MA (1997) Enhancement of humoral and cellular immunity by vitamin E after embryonic exposure. Poultry Science 76, 984-991.

Hannigan BM (1994) Diet and immune function. British Journal of Biomedical Sciences 51, 252-259.

Hatchigian EA, Santos JL, Broitman SA \& Vitale JJ (1989) Vitamin A supplementation improves macrophage function and bacterial clearance during experimental salmonella infection. Proceedings of the Society for Experimental Biology and Medicine 191, 47-54.

Hauck CR, Lorenzen D, Saas J \& Meyer TF (1997) An in vitrodifferentiated human cell line as a model system to study the interaction of Neisseria gonorrhoeae with phagocytic cells. Infection and Immunity 65, 1863-1869.

Hughes DA (1999) Effects of dietary antioxidants on the immune function of middle-aged adults. Proceedings of the Nutrition Society 58, 79-84.

Keusch GT (1998) Nutrition and immunity: from A to Z. Nutrition Reviews 56, S3-S4.

Knudsen CA, Tappel AL \& North JA (1996) Multiple antioxidants protect against heme protein and lipid oxidation in kidney tissue. Free Radical Biology and Medicine 20, 165-173.

Kriska T, Gamaley I, Vasvári G, Holly S, Maltseva E, Strizhak P \& Gál D (1999) Quantitative studies on the respiratory burst generated in peritoneal macrophages. Journal of Photochemistry and Photobiology, Part B: Biology 50, 159-165.

Lissi E, Salim-Hanna M, Pascual C \& del Castillo MD (1995) Evaluation of total antioxidant potential (TRAP) and total antioxidant reactivity from luminol-enhanced chemiluminescence measurements. Free Radical Biology and Medicine 18, $153-158$

McCall MR \& Frei B (1999) Can antioxidant vitamins maternally reduce oxidative damage in humans? Free Radical Biology and Medicine 26, 1034-1053.
Matthews KS, Mrowczynski E \& Matthews R (1994) Dietary deprivation of B-vitamins reflected in murine splenocyte proliferation in vitro. Biochemical and Biophysical Research Communications 198, 451-458.

Meydani M, Lipman RD, Han SN, Wu D, Beharka A, Martin KR, Bronson R, Cao G, Smith D \& Meydani SN (1998) The effect of long-term dietary supplementation with antioxidants. Annals of the New York Academy of Sciences 854, 352-360.

Moriguchi S, Kobayashi N \& Kishino Y (1990) High dietary intakes of vitamin $\mathrm{E}$ and cellular immune functions in rats. Journal of Nutrition 120, 1096-1102.

Moriguchi S, Werner L \& Watson RR (1985) High dietary vitamin A (retinyl palmitate) and cellular immune functions in mice. Immunology 56, 169-177.

Mosca L, Rubenfire M, Mandel C, Rock C, Tarshis T, Tsai A \& Pearson T (1997) Antioxidant nutrient supplementation reduces the susceptibility of low density lipoprotein to oxidation in patients with coronary artery disease. Journal of the American College of Cardiology 30, 392-399.

Mulero V, Esteban MA \& Meseguer J (1998) Effects of in vitro addition of exogenous vitamins $\mathrm{C}$ and $\mathrm{E}$ in gilthead seabream (Sparus aurata L.) phagocytes. Veterinary Immunology and Immunopathology 66, 185-199.

National Research Council (2001) Recommended Dietary Allowances, 11th edn. Washington, DC: National Academy Press.

Németh A, Jakus J, Kriska T, Keszler Á., Vanyúr R \& Gál D (1999) Physico chemical modeling of the role of free radicals in photodynamic therapy. IV. Quantitative aspects of photodynamic effects on free radicals generated in cell cultures. Biochemical and Biophysical Research Communications 255, 360-366.

Nikki E (1987) Interaction of ascorbate and $\alpha$-tocopherol. Annals of the New York Academy of Sciences 498, 186-199.

Nyyssonen K, Porkkala E, Salonen R, Korpela H \& Salonen JT (1994) Increase in oxidation resistance of atherogenic serum lipoproteins following antioxidant supplementation: a randomized double-blind placebo-controlled clinical trial. European Journal of Clinical Nutrition 48, 633-642.

Palozza P \& Krinsky NI (1992) $\beta$-Carotene and $\alpha$-tocopherol are synergistic antioxidants. Archives of Biochemistry and Biophysics 297, 184-187.

Reynolds ES \& Moslen MT (1980) Free Radicals in Biology, vol. IV, pp. 49-94 [WA Pryor, editor]. London, UK: Academic Press Inc.

Rockenbauer A \& Korecz L (1996) Automatic computer simulation of ESR spectra. Applied Magnetic Resonance 10, 29-43.

Rücker M, Finckh B, Kohlschütter A, Menger MD \& Vollmar B (1997) Dietary vitamin E does not protect from endotoxininduced hepatic microvascular dysfunction. Cellular and Molecular Life Sciences 53, 294-302.

Sharmanov TSh (1982) Nutrition and immunity. Voprosy Pitania $\mathbf{5}, 3-8$.

Shulyakovskaya T, Sümegi L \& Gál D (1993) In vivo experimental studies on the role of free radicals in photodynamic therapy. I. Measurement of the steady state concentration of free radicals in tumor tissues of mice. Biochemical and Biophysical Research Communications 195, 581-587.

Surai PF, Noble RC \& Speake BK (1996) Tissue-specific differences in antioxidant distribution and susceptibility to lipid peroxidation during development of the chick embryo. Biochimica et Biophysica Acta 1304, 1-10.

Tappell AL (1962) Vitamin E as the biological lipid antioxidant. Vitamins and Hormones 20, 493-510.

Thomas SR, Neuzil J \& Stocker R (1996) Cosupplementation with coenzyme $\mathrm{Q}$ prevents the prooxidant effect of $\alpha$-tocopherol and increases the resistance of LDL to transition metal-dependent oxidation initiation. Arteriosclerosis, Thrombosis and Vascular Biology 16, 687-696. 